\title{
sciendo
}

CIVIL AND ENVIRONMENTAL ENGINEERING REPORTS

E-ISSN 2450-8594

CEER 2021; 31 (1): 0192-0199

DOI: $10.2478 /$ ceer-2021-0014

Original Research Article

\section{CARBON ACCUMULATION POTENTIAL FROM NATURAL FOREST REGROWTH OF GODECH MUNICIPALITY, WESTERN BULGARIA}

\author{
Borislav GRIGOROV ${ }^{1}$ \\ Faculty of Geology and Geography, University of Sofia "St. Kliment Ohridski”, 15 Tzar \\ Osvoboditel Blvd., 1504 Sofia, Bulgaria
}

\begin{abstract}
The present research deals with carbon sequestration, as an important process for mitigating the effects of climate change. The investigation focuses on a 30 -year period and it covers only aboveground biomass that builds up from natural forest regrowth, excluding any plantation techniques. Potential carbon sequestration rate from natural forest regrowth in Godech Municipality was measured in $\mathrm{Mg} \mathrm{C} \mathrm{ha-1} \mathrm{yr}^{-1}$ and the resolution of the map was $1 \mathrm{x} 1 \mathrm{~km}$. The results of the study display that carbon accumulation values in the researched area were consistent with those that were expected in the largest parts of Bulgaria. The biggest share of Godech Municipality falls within the range of $0.82-0.96 \mathrm{Mg} \mathrm{C} \mathrm{ha}^{-1} \mathrm{yr}^{-1}$ with restricted areas around the villages of Barlya, Smolcha, Gubesh, Murgash and Varbnitsa that may accumulate between $0.96-1.11 \mathrm{Mg} \mathrm{C} \mathrm{ha}^{-1} \mathrm{yr}^{-1}$. In conclusion, carbon accumulation only from natural forest regrowth provides representative information, however it would have been better if different plantation techniques were regarded as well. The successful results of the investigation should encourage other studies of this type in the neighbouring municipalities.
\end{abstract}

Keywords: natural forest regrowth, climate change mitigation, carbon sequestration

\footnotetext{
${ }^{1}$ Borislav Grigorov: Faculty of Geology and Geography, University of Sofia "St. Kliment Ohridski”, 15 Tzar Osvoboditel Blvd., 1504 Sofia, Bulgaria, borislav.g.grigorov@gmail.com, +359029308361
} 


\section{INTRODUCTION}

Enhancing global response to ongoing changes in climate is a crucial goal nowadays. The $1.5^{\circ} \mathrm{C}$ baseline above preindustrial levels is being discussed by the minute [18], and scientists throughout the world are competing to get the results we all need [12]. Carbon sequestration potential is one of the most discussed mechanisms for climate change mitigation. Despite the fact that soils are regarded as the largest carbon pool among terrestrial ecosystems, aboveground carbon storages are not to be underestimated. The extension of the forest cover provides gains, not only regarding the field of climate change, but also considering the perspective of the concept of ecosystems goods and services. By extension of the natural forest cover, i.e., a natural regrowth, and not through planting on an area, where the anthropogenic disturbance is restricted. It has been argued lately that natural forest regrowth represents a process of a better recovery when compared to active forest restoration.

A number of researchers discuss the problems of climate change, focusing on the importance of forests. A study by Schlup et al. [23] focuses on the future of carbon storages in Europe. Other authors [e.g., 4,11,13] argue about the potential of afforestation for climate change mitigation and discuss the benefits from forest regeneration. Researchers aim at studying the aboveground alpine carbon pool [24] and also conduct a review on a global scale, concerning past land use, climate, active and passive restoration effects on forest recovery [19]. They present a global database of forest carbon stocks and fluxes [2] and focus on the investigation of the effects of the natural forest regeneration [22], as well. Authors also discuss the restoration potential of trees on a global scale [3]. Another study by Lewis et al. [17] is based on the regeneration potential of natural forests to store carbon, and other authors raise a discussion, based on the real part that trees will play in climate change [14], while other scientists [21] aimed at predicting trees' ability to sequester carbon after the application of land restoration techniques. Data availability on climate change developed also by the contribution of other authors $[5,10]$. At the same time $[15,20]$ work on the creation of different methodologies.

The geographical space of Bulgaria has been an arena for investigations, based on carbon sequestration, as well. Teams of scientists $[27,28,29]$ investigated carbon storages in Belasitsa Mountain, the territory of the Western Rhodopes and also focused on the investigation of the carbon sequestration potential of forest ecosystems in Bulgaria. Other researchers focused on a particular soil type. [1] Researchers also studied representative forest ecosystems in Bulgaria and conducted an investigation, focused on the area of Karlovo Municipality, as well $[9,16]$. 
The importance of carbon sequestration is recognized in the National Forestry Accounting Plan for Bulgaria 2021-2025 [25], and this was one of the reasons that sparked the scientific interest towards the current research. With the projected emissions and removals from living biomass, both from coniferous and deciduous forests for Bulgaria, only for 2021 to be $-4710.66 \mathrm{GgCO}_{2}$, therefore each step towards carbon accumulation is more than welcomed. Moreover, the part that Godech Municipality is taking in this process should not be taken lightly. The necessity of a research of this kind at Godech Municipality is unquestionable. The predominantly mountainous character of it allows for high rates of natural forest regrowth that will play their essential part in climate change mitigation. This is a pioneer research on this particular matter that will provide interesting results. Apart from the introduction and the results, the other main sections of it are the methodology, conclusion and evaluation. Acknowledgments and a reference list are provided in the end.

\section{MATERIALS AND METHODS}

The focus of the current investigation is to present the carbon sequestration rate of the aboveground live biomass, focused specifically on the carbon, accumulated from the atmosphere. The present research is based on the work of a group of researchers [8] who view forest restoration, as the shift from "less than $25 \%$ tree cover to more than $25 \%$ tree cover" particularly in territories that are known to have been characterized by a forest cover from a historical perspective. The authors of the study created a machine learning model, based on terrain measurements from all over the world.

The territory of Godech Municipality, which has been used as the case study area for the current study, lies along the ancient Roman road of Via Militaris or Via Diagonalis that passed through the Great Bulgarian Forest (Magna Silva Bulgarica) - a proof that the municipality has been covered by an extensive forest, which is the necessary requirement for the purposes of the current study.

Godech Municipality is located in a predominantly mountainous territory, built up of the ranges of Berkovska Mountain and Ponor Mountain from Western Stara Planina to the north and the mountains of Vuchibaba, Vidlich and Chepun, situated in the central and southern parts. A broader valley lies to the south - the Godech Valley, however its territorial extent is incomparable to that of the mountain ranges. These geographic specifics of Godech Municipality provide a considerable potential for forest growth, accompanied by the fact that some of the locations are remote and not easy to reach.

Natural forest regrowth, in particular, is representing the basis of the present investigation, thus agroforestry processes and other different restoration techniques with anthropogenic origin are excluded from it. Soil organic carbon 
and carbon accumulation in the belowground biomass are also ruled out from the study. There is a strictly followed period for the finalization of this process, equalling to the first 30 years of natural forest regrowth. This period extends till the year of 2050 - a deadline for accomplishing the zero emission baselines. If it is surpassed, there may be a biased overestimation of the sequestration. It is important to be stressed on the fact that this measurement is conducted without taking the current land cover into account, as well as the already known reforestation potential. Potential carbon sequestration rate from natural forest regrowth is measured in $\mathrm{MgC} \mathrm{ha} \mathrm{Cr}^{-1} \mathrm{yr}^{-1}$ and the resolution of the map is $1 \mathrm{x} 1 \mathrm{~km}$ [25].

\section{RESULTS}

The values applying for the whole world fall between the range of 0.06 and 6.0 $\mathrm{Mg} \mathrm{C} \mathrm{ha}{ }^{-1} \mathrm{yr}^{-1}$. As it can be viewed from the cited studies [6,7] areas with tropical forests, such as those in the Amazon Basin and the Congo Basin, are competing for the highest results and this is not unexpected. These research $[8,26]$ also contributes to this data. It is known that the accumulation of carbon occurs in a faster rate in humid and warm climate than in dry and cold climate. Another principle that has to be taken in mind is that if a more intense disturbance in the forests occurs, and if there are lower levels of initial biomass quantity, then higher carbon accumulation rates can be expected. The predominantly temperate European territory cannot achieve such high results and Ireland and the Western parts of Britain are standing out. As the territory of Bulgaria is concerned, the areas that are located in the easternmost parts of Stara Planina Mountain, as well as Strandzha Mountain are having values between 1.11 and $1.28 \mathrm{Mg} \mathrm{C} \mathrm{ha}^{-1} \mathrm{yr}^{-1}$. The values for Gornotrakiiska Valley, the northeastern parts of Dobrudzha and parts of Belasitsa Mountain are $0.65-0.82 \mathrm{MgC} \mathrm{ha}^{-1} \mathrm{yr}^{-1}$. The rest of the country falls within the ranges between 0.82 and $1.11 \mathrm{Mg} \mathrm{C} \mathrm{ha}^{-1} \mathrm{yr}^{-1}$.

In general, the carbon accumulation potential from natural forest regrowth in Godech Municipality follows the pattern that is typical for the most parts of Bulgaria and fall within the range of $0.82-0.96 \mathrm{Mg} \mathrm{C} \mathrm{ha}^{-1} \mathrm{yr}^{-1}$ (Fig. 1). 


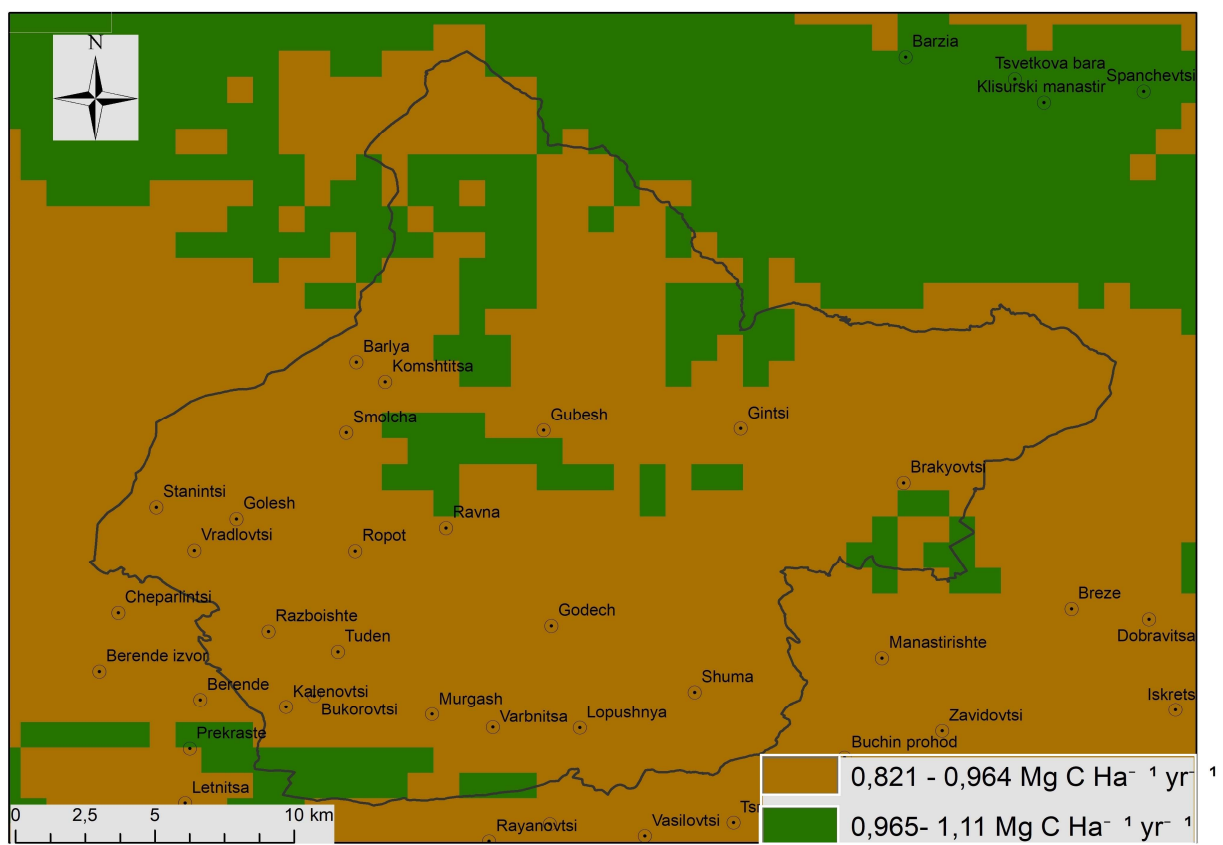

Fig. 1. Carbon accumulation potential in Godech Municipality after forest regrowth

These territories are predominantly located in a northwestern-southeastern direction from the villages of Stanintsi, Golesh and Vradlovtsi to the town of Godech and the village of Shuma. This is not a surprise, because this territory is predominantly taken by Godech Valley, therefore not possessing the highest carbon accumulation potential when natural forest regrowth is considered.

The territories that are characterized by a higher carbon sequestration potential are following the mountainous pattern in some way with mountains of Berkovska and Ponor to the north and Chepun Mountain to the south. Here values are falling within the range of 0.96 and $1.11 \mathrm{Mg} \mathrm{Cha}^{-1} \mathrm{yr}^{-1}$. If we have to be more specific, these areas are located to the north of the villages of Barlya, Komshtitsa, Gubesh and Gintsi, in the triangle between the villages of Smolcha, Gubesh and Ravna, to the south of the villages of Kalenovtsi, Bukorovtsi, Murgash and Varbnitsa and to the south of Brakyovtsi.

The results of the study show a distinctive pattern in which mountainous areas possess a larger potential for carbon accumulation, compared to areas with a lower elevation, however this should not be always assumed as regularity, because there may be exceptions of this rule. However, this is the case in Godech Municipality and it should be taken into account by policy-makers in their programs. 


\section{CONCLUSION AND EVALUATION}

The current investigation shows some promising results. Carbon accumulation in Godech Municipality varies between $0.82-0.96$ and $0.96-1.11 \mathrm{Mg} \mathrm{C} \mathrm{ha}^{-1} \mathrm{yr}^{-1}$ with the highest results near the villages of Brakyovtsi, Ravna, Gubesh, Gintsi, Barlya and Komshtitsa. These values are consistent with those, typical for the most parts of Bulgaria. Despite the fact, that they are lower than the highest possible accumulation rates that may be expected in Eastern Stara Planina Mountain and Strandzha Mountain, this does not lead to the assumption that carbon sequestration in the studied territory is not of a great importance. On the contrary, the study is essential, because it proves the key role of Godech Municipality for climate change mitigation in Western Bulgaria.

There are some weak points that have to be regarded in the overall evaluation. Cook-Patton et al. [8] admit that there can be uncertainties, depending on the location of the maps and availability of data, and they confirm that the prominent on-situ assessments are always a good idea. Carbon accumulation only from natural forest regrowth provides representative information, however it would have been better if different plantation techniques were regarded as well, because it undoubtedly would have provided a broader picture. Overall, carbon sequestration happens in all aboveground biomass, regardless of its origin and way of forming. More should also be done in terms of terrain research in order to get more sufficient data for making assumptions.

Nevertheless, our investigation of the accumulation of carbon in aboveground biomass in Godech Municipality provides sufficient data for policy-making. The successful results of the study may serve as a model for the conduction of similar research in the neighbouring municipalities.

\section{ADDITIONAL INFORMATION}

This research is conducted with financial support of the National Scientific Programme "Young scientists and postodoctoral students" 2020 and the National Science Fund (Contract ДКОСТ 01/7/19.10.2018).

\section{REFERENCES}

1. Assenov, A, Saraffov, A and Bozhkov, P 2017. Ecosystem/landscape services provided by Umbrosols (UM) in selected mountainous municipalities of Sofia District. Comptes rendus de l'Academie bulgare des Sciences, Geologie: 69 (3): 319-326.

2. Anderson-Teixeira, $\mathrm{K}$ et al. 2018. ForC: a global database of forest carbon stocks and fluxes. Ecology 99, 1507. 
3. Bastin, J et al. 2019. The global tree restoration potential. Science 365, 7679.

4. Betts, R 2011. Climate science: afforestation cools more or less. Nat. Geosci. 4, 504-505.

5. Burciaga, U 2020. Sustainability assessment in housing building organizations for the design of strategies against climate change. HighTech and Innovation Journal 1 (4), 136-147.

6. Chaturvedi, R et al. 2011. Carbon density and accumulation in woody species of tropical dry forest in India. Forest Ecology and Management 262 (8), 15761588.

7. Chaturvedi, R and Raghubanshi, A 2015. Assessment of carbon density and accumulation in mono- and multi-specific stands in Teak and Sal forests of a tropical dry region in India 2015, Forest Ecology and Management 339, 1121.

8. Cook-Patton, S, Leavitt, S, Gibbs, D et al., 2020. Mapping carbon accumulation potential from global natural forest regrowth. Nature 585, 545550 .

9. Dimitrova, V, Lyubenova, M and Vanguelova, E 2014. Biomass and carbon accumulation in herb layer of representative forest ecosystems in Bulgaria. Journal of Balkan Ecology 17 (1), 55-71.

10. Fenu, G and Malloci, F 2020. DSS LANDS: A decision support system for agriculture in Sardinia. HighTech and Innovation Journal 1(3), 129-135.

11. Gilroy, J et al. 2014. Cheap carbon and biodiversity co-benefits from forest regeneration in a hotspot of endemism. Nat. Clim. Chang. 4, 503-507.

12. Griscom, B et al. 2017. Natural climate solutions. Proc. Natl Acad. Sci. USA 114, 11645-11650.

13. Grassi, G et al. 2017. The key role of forests in meeting climate targets requires science for credible mitigation. Nat. Clim. Chang. 7, 220-226.

14. Holl, $\mathrm{K}$ and Brancalion, $\mathrm{P}$ 2020. Tree planting is not a simple solution. Science 368, 580-582.

15. Javadinejad, S, Rebwar, D, Jafary F 2020. Climate Change Scenarios and Effects on Snow-Melt Runoff. Civil Engineering Journal 6 (9), 1715-1725.

16. Koulov, B, Ivanova, E, Borisova, B, Assenov, A, Ravnachka, A 2017. GISbased Valuation of Ecosystem Services in Mountain Regions: A Case Study of the Karlovo Municipality in Bulgaria. One Ecosystem 2: e14062.

17. Lewis, S, Wheeler, C, Mitchard, E and Koch, A 2019. Regenerate natural forests to store carbon. Nature 568, 25-28.

18. Masson-Delmotte, $\mathrm{V}$ et al. (eds) 2018. Global Warming of $1.5^{\circ} \mathrm{C}$. An IPCC Special Report on the Impacts of Global Warming of $1.5^{\circ} \mathrm{C}$ Above Preindustrial Levels and Related Global Greenhouse Gas Emission Pathways, in the Context of Strengthening the Global Response to the Threat of Climate 
Change, Sustainable Development, and Efforts to Eradicate Poverty (IPCC, 2018).

19. Meli, P. et al. 2017. A global review of past land use, climate, and active vs. passive restoration effects on forest recovery. PLoS One 12, e0171368.

20. Oo, H, Zin, W and Kyi, C 2020. Analysis of streamflow response to changing climate conditions using SWAT model. Civil Engineering Journal 6 (2), 194209.

21. Paul, K and Roxburgh, S 2020. Predicting carbon sequestration of woody biomass following land restoration. For. Ecol. Manage. 460, 117838.

22. Reid, J, Fagan, M and Zahawi, R 2018. Positive site selection bias in metaanalyses comparing natural regeneration to active forest restoration. Sci. $A d v$. 4, eaas9143.

23. Schlup, K, Nabuurs, G, Verburg, P 2008. Future carbon sequestration in Europe - effects of land use change. Agriculture, Ecosystems \& Environment.127 (3-4), 251-264.

24. Speed, J, Martinsen, V, Mysterud, A, Holand, O andAustrheim, G 2014. Long-term increase in aboveground carbon stocks following exclusion of grazers and forest establishment in an alpine ecosystem. Ecosystems 17, $1138-1150$.

25. Stoeva, L, Markoff, I and Zhiyanski, M 2018. National Forestry Accounting Plan for Bulgaria, Including Forest Reference Levels for the Period 20212025 (Ministry of Environment and Water, Republic of Bulgaria); https://www.moew.government.bg/static/media/ups/articles/attach ments/NFAP_final_ENe30a12d4d7dff0f589ad84b69bb90b12.pdf.

26. Accessed through Global Forest Watch on [30.09.2020]. www.globalforestwatch.org).): Cook-Patton et al. 2020. Uncertainty in carbon accumulation potential from natural forest regrowth in forest and savanna biomes.

27. Zhiyanski, M, Glushkova, M 2013. Carbon storage in selected European chestnut (Castanea sativa Mill.) ecosystems in Belasitsa Mountain, SW Bulgaria. Silva Balcanica, 14 (1), 60-75.

28. Zhiyanski, M, Glushkova, M, Ferezliev, A, Menichetti, L, Leifeld, J 2016. Carbon storage and soil property changes following afforestation in mountain ecosystems of the Western Rhodopes, Bulgaria. iForest, 9, SISEF - Italian Society of Silviculture and Forest Ecology, ISSN:1971-7458, DOI:10.3832/ifor 1866-008, 626-634.

29. Zhiyanski, M 2020. Forest ecosystems in Bulgaria under environmental change - carbon sequestration potential and vulnerability zones. In: Smart Geography (eds. S. Nedkov, G. Zhelezov, N. Ilieva, M. Nikolova, B. Koulov, K. Naydenov, S. Dimitrov), 417-441.

Editor received the manuscript: 05.11 .2020 